\title{
Йосип СВОРЕНЬ
}

Інститут геології і геохімії горючих копалин НАН України, Львів, e-mail: igggk@mail.lviv.ua

\section{НАДРА ЗЕМЛІ - ПРИРОДНИЙ ФІЗИКО-ХІМІЧНИЙ РЕАКТОР: ПОШУК ПРИРОДНОГО МЕТАНУ - ФУНДАМЕНТАЛЬНА НАУКА ЧИ ТЕХНІЧНА ПРОБЛЕМА?}

Показано, що гіпотеза органічного походження вуглеводнів не дає відповіді щодо наявності домінувальної концентрації метану в покладах, родовищах, «сланцевих» товщах тощо, відповідно пошук і розвідка родовищ-покладів вуглеводнів у них проводиться переважно інтуїтивно, а не на фундаментальній науковій базі. Експериментальними дослідженнями прогріву слабкозміненої органічної речовини (торфу) встановлено, що до $200{ }^{\circ} \mathrm{C}$ у процесі ії розкладу виділилися такі гази, як (об. \%): $\mathrm{CO}_{2}=49,5 ; \mathrm{H}_{2} \mathrm{O}=49,3 ; \mathrm{CH}_{4}, \mathrm{C}_{2} \mathrm{H}_{6}, \mathrm{C}_{3} \mathrm{H}_{8}, \mathrm{O}_{2}, \mathrm{~N}_{2}, \mathrm{H}_{2}, \mathrm{SO}_{2}, \mathrm{H}_{2} \mathrm{~S}$ сумарно в межах 1,2 відсотка. Стверджено, що немає метану вугільного і немає сланцевого газу-метану, $\epsilon$ метан однієї генези з дещо відмінним ізотопним складом Карбону, однак синтезований за одним і тим самим механізмом у високотермобарних процесах, який після міграції в земну кору нагромаджувався у вигляді покладів-родовищ у порожнинах вугільних пластів, теригенних товщах, пісковиках тощо. Пошуки родовищ-покладів вуглеводнів необхідно проводити відповідно до розроблених «нової технології визначення перспективи нафтогазоносності локальної площі», «фізико-хімічної моделі синтезу вуглеводнів та способу геохімічного пошуку їхніх покладів», «нової теоpiї синтезу і генезису вуглеводнів у літосфері Землі: абіогенно-біогенний дуалізм».

Ключові слова: флюїдні включення, мінерали, метан, походження вуглеводнів, пошуки, поклади-родовища, нові технології.

Україна має серйозну проблему з енергоносіями, зокрема 3 природним газом і нафтою, якими забезпечена в межах 40-60 \% від потреб. Незважаючи на рентабельність геологорозвідувальних робіт, ця галузь перебуває в кризовому стані через недостатне фінансування та правове забезпечення праці в ринкових умовах господарювання. Останніми роками видобуток газу і нафти в державі перевищував приріст їхніх запасів, що свідчить про занепад нафтогазової промисловості. Із цієї причини Україна потрапляє в залежність від зовнішніх поставок цих енергоносіїв, насамперед, від російських. Навіть якби держава різко скоротила споживання газу промисловістю, вона при такій політиці буде вимушена і надалі імпортувати ці енергоносії. Тому необхідно вживати заходи щодо забезпечення власними газом і нафтою. Надра України вивчені ще недостатньо, хоча великі родовища, за твердженням деяких спеціалістів, нібито вже вичерпані, тому пропонується забезпечувати себе за рахунок середніх та малих родовищ, що не зовсім відповідає дійсності. Наші природні ресурси розвідані і видобуті лише на $35 \ldots 40 \%$, та й сумарні

(C) Йосип Сворень, 2019

ISSN 0869-0774. Геологія і геохімія горючих копалин. 2019. № 4 (181) 
витрати на пошуки і видобуток однієї тонни умовного палива на родовищах України в багато разів нижчі за світові ціни. Насправді відомості про те, скільки вуглеводнів ще вміщає планета Земля і за яких фізико-хімічних умов і в яких місцях проходить їх синтез-утворення, загалом ще неоднозначні.

Основними причинами кризового стану в нафтогазовому комплексі України $€$ недостатнє фінансування фундаментальної науки, пошуково-розвідувальних робіт та їхня відірваність від експлуатаційних-видобувних підприємств, використання застарілих технологій пошуку та розвідки родовищ газу і нафти та інших корисних копалин, використання застарілого устаткування тощо.

Виходячи зі сказаного, доцільним було б створення підприємства для проведення пошуково-розвідувальних та експлуатаційних-видобувних робіт, яке брало б за основу фундаментальні наукові результати і нові технології пошуку та розробки родовищ з буріння свердловин українських учених, які є особливо перспективні сьогодні і до яких автор має безпосереднє відношення.

Геологорозвідувальні роботи в різних регіонах планети Земля показали, що достатньо потужні товщі високовуглецевих теригенних порід у певних типах геотектонічних структур можуть вміщати промислово важливі поклади нафти і газу, а також великі за запасами родовища золота та інших рудних корисних копалин, однак походження цих родовищ, а відповідно і підходи до розробки їхніх прогнозних та пошуково-оцінних критеріїв, зокрема і термобаричних, і геохімічних, усе ще залишаються дискусійними. Особливо гостро це відчувається в Україні, де теригенні товщі досить таки детально розвідані на нафтові родовища на малих і середніх глибинах. Також практика свідчить, що часто нафтогазові родовища при традиційному підході до випробування пошукових бурових свердловин у теригенних товщах можуть бути і не виявлені. Подібна ситуація ще більше ускладнюється на великих глибинах і в товщах вапняків, де ефективність відомих геофізичних та інших методів поки що явно недостатня.

Отже, назріла потреба в принципово нових підходах і матеріалах щодо закономірностей локалізації в теригенних товщах різних типів родовищ корисних копалин, насамперед вуглеводнів, та особливостей їхніх ореолів: термобаричних, геохімічних тощо.

Наші теоретичні й експериментальні дослідження показали, що одним iз найяскравіших природних феноменів таких ореолів $\epsilon$ наявні прояви прожилково-вкрапленої мінералізації, зокрема і на продовженні продуктивних горизонтів. Ці результати дали нам підстави оприлюднити новий науковий напрямок у геології: «термобарометрія і геохімія газів прожилкововкрапленої мінералізації у відкладах нафтогазоносних областей і металогенічних провінцій» (Сворень, 1984, 1992; Сворень та ін., 1994; Сворень, Давиденко, 1994, 1995).

Якщо брати до уваги те, що з часом пошук та розвідка родовищ нафти i газу будуть пов'язані з великими глибинами та неосвоєними теренами, освоєння яких пов'язане із значними затратами (вартість лише геолого-геофізичних робіт з глибиною значно зростає (у млн грн)), а їхні темпи сповільнюються, то особливо актуальними $є$ завдання розробок також нових технологій пошуку і розвідки вуглеводнів на конкретних площах. 
Розроблена нами (Сворень, Давиденко, 1994, 1995; Сворень та ін., 1998) «нова технологія визначення перспективи нафтогазоносності локальної площі〉 належить до мінералого-геохімічних способів пошуків покладів корисних копалин та використовується для локального прогнозу покладів нафти і газу. Міграція та нагромадження вуглеводнів в осадових товщах супроводжуються розвитком у вмісних породах прожилково-вкрапленої мінералізації з певним складом флюїдних включень у прожилкових мінералах. Інтенсивність насичення цих мінералів флюїдними включеннями і спектр речовинного складу останніх тісно пов'язані з характером та масштабом самих покладів вуглеводнів. При цьому нафтогазонасиченість прожилків мінералів, зокрема карбонатів, на порядок і більше вища від тих величин, які можна отримати аналізом породи з ореолів покладів, а речовинний склад флюїдних включень прожилкових мінералів більш повно характеризує сам поклад. Це дає підставу розглядати прожилково-вкраплену мінералізацію в осадових товщах нафтогазоносних областей як достатньо чіткий індикатор наявності на глибині чи на певній відстані за латераллю покладів-родовищ вуглеводнів.

За технологією, про знаходження локальної нафтогазоносної площі стверджують за наявністю і характером росту величини відношення концентрацій вуглеводнів у включеннях прожилково-вкраплених мінералів до концентрації вуглеводнів у дефектах-порах порід, які містять ці прожилки, при цьому за величиною цього відношення, що знаходиться в межах від одиниці до кількох сотень одиниць, визначають як напрямок безпосередніх пошуків, так i вірогідне розташування нафтогазового покладу чи родовища. Вона дає змогу підвищити достовірність і точність визначення перспективи нафтогазоносності локальної площі за даними вивчення флюїдних включень у мінералах 3 керна свердловини і одночасно зекономити кошти на бурові роботи за $300 \ldots 500$ м до проєктної відмітки та продовжити бурові роботи глибше цієї відмітки на таку саму відстань за отриманими результатами.

Наявні факти спонукають нас запропонувати будівництво пошукової свердловини, яка буде розташована між св. 1-Саджавська і Космацьким газоконденсатним родовищем на відстані $0,5 \ldots 3,0$ км від центра свердловини 3 проєктною глибиною 4,5 км (Наумко, Сворень, 2014). При цьому буріння (роторне) на відтинку від 3,5 до 4,5 км глибини має здійснюватися 3 отриманням керна, необхідного для його паралельного наукового вивчення, відповідно до вимог розробленої технології, яка дозволяє також вказувати напрям буріння, тобто, проводити буріння похило спрямованих і горизонтальних свердловин.

Такі свердловини паралельно переходять у розряд свердловин, за даними буріння яких отримують вагомі наукові результати, отож їх можна вважати т. зв. науковими свердловинами, бо дають змогу отримати фундаментальні знання про речовинний склад, фазовий стан, температуру, тиск та густину флюїдів, склад, будову, динаміку й еволюцію земної кори, про перенос геотермальної енергії, розподіл мінеральних покладів, знаходження корисних копалин, про природу та розподіл підземних вод у надрах різних держав, що дуже важливо для кожного народу, який зобов'язаний знати багатства своїх надр, наділених йому Богом. 
Розроблену нами технологію успішно апробовано в межах нафтогазоносних провінцій України: Передкарпатті, Закарпатті, Дніпровсько-Донецької западини тощо. Вона корисна як приватним фірмам чи корпораціям, що запрограмовані на швидкі результати та економію коштів, так і дослідникам, яких, передусім, цікавить фундаментальна інформація.

Також розроблена (Давиденко, Сворень, 1994; Svoren' et al., 1999) «нова технологія локального прогнозування збагачених ділянок золоторудних полів», яка належить до пошукової геології та геохімії і може бути використана для локального мінералого-геохімічного прогнозування покладів золота та інших кольорових металів і визначення перспективного напрямку робіт. Вона пройшла успішну перевірку на відомих родовищах: Мурунтау (Узбекистан), Кубака (Магаданська область Росії), Закарпатті тощо.

«Фізико-хімічною моделлю синтезу вуглеводнів і способом геохімічного пошуку їх покладів» (Сворень, 1992) показано, що зі сторони мантії Землі під дією потужного імпульсу тектоногенної енергії в літосфері виникає глибинний розрив-розлом, у порожнину якого в напрямку до земної кори втілюється високотермобарний флюїд із мінеральною та вуглеводеньвмісною складовими (Наумко, Сворень, 2003), які в контактних породах утворюють безліч макро- і мікротріщин, закономірно орієнтованих за радіусами від центра цієї області. Значні тиски, високі температури, активні каталізатори, високовольтне електричне поле та інші фізико-хімічні чинники призвели до різкої зміни складу флюїдів. Леткі сполуки розклалися на окремі атоми і радикали, зокрема, вуглеводеньвмісні - на атомарні водень, вуглець та $\mathrm{C}_{n} \mathrm{H}_{m}$-радикали, які пізніше синтезували складні вуглеводні. Паралельно із синтезом вуглеводнів утворюються і такі мінерали, як кальцит, кварц, барит, флюорит, «мармароські діаманти», кварц-карбонатна порода тощо. Виходячи з факту, що згадані мінерали та породи формуються в середовищі високотермобарного флюїду, його захоплення дефектами - включеннями в новоутворених прожилкових мінералах, які заліковують ці макро- і мікротріщини, раніше утворені в контактних породах, не викликає заперечень. Втілення високотермобарного флюїду в розглядувану область супроводжується потужним стисненням як складових флюїду, так і наявних там сполук, виділених із контактних порід разом з органічними рештками, що призвело до стрибка зростання температури і тиску додатково за рахунок внутрішньої енергії системи внаслідок адіабатичного процесу (Сворень, Наумко, 2003). Ці фізико-хімічні чинники створили різкі градієнти температури і тиску, призвели до утворення додаткової множини макро- та мікротріщин у контактних породах і мінералах, які при заліковуванні мінеральною складовою цього флюїду законсервували середовище та фізико-хімічні умови в просторі і часі своїми дефектами-включеннями.

Високі температури, великі тиски, високовольтне електричне поле та інші складні фізико-хімічні чинники сприяли розкладові розмаїтих вуглеводеньвмісних речовин на окремі атоми і радикали з іонізацією. Одночасно дія електричного поля створила оксидну та відновну області, у яких іонізовані частинки розділяються за своїми зарядами і закономірно розподіляються в згаданих областях середовища. У відновній області синтезується складна суміш вуглеводнів, а в оксидній - утворюються мінерали-оксиди. 
Важливо додати, що синтезований за такою схемою і за високих температур та тисків метан разом із мінеральною складовою флюїду був джерелом великої теплової енергії та переносником значних мас мінеральної сировини, 3 якої утворилися досконалі мінерали та кварц-карбонатна порода, які щільно і герметично залікували тріщини різних розмірів.

Проблемою сьогодення є встановлення природи «сланцевого» газу, тобто його походження. Сланцеві породи $є$ щільними, мають низьку пористість та проникність, вміщають газ у малих концентраціях. Тому для видобутку газу 3 них використовують гідравлічний розрив пласта, що вимагає постійного буріння нових свердловин та освоєння великих площ. Вважається, що наявний у сланцевих породах метан має органічне походження, тобто, він утворився 3 органічних решток у процесах катагенезу.

На рисунку показано температурну залежність концентрацій летких сполук із торфу. По осі абсцис подано зміну температури, а по осі ординат відкладено відсотковий вміст $(\mathrm{C}, \%)$ летких речовин, отриманих у процесі розкладу торфу під час нагрівання. Кількісний склад летких речовин для будьякої температури можна визначити за розрізами, паралельними осі ординат. Діоксид вуглецю і вода утворюються-виділяються першими та в найбільших концентраціях. Зокрема, за температури $200{ }^{\circ} \mathrm{C}$ виділилися леткі сполуки в таких кількостях (об. \%): $\mathrm{CO}_{2}=49,5 ; \mathrm{H}_{2} \mathrm{O}=49,3 ; \mathrm{CH}_{4}, \mathrm{C}_{2} \mathrm{H}_{6}, \mathrm{C}_{3} \mathrm{H}_{8}, \mathrm{O}_{2}, \mathrm{~N}_{2}, \mathrm{H}_{2}$, $\mathrm{SO}_{2}, \mathrm{H}_{2} \mathrm{~S}$ сумарно в межах 1,2 відсотка. За температури $400{ }^{\circ} \mathrm{C}$ виділення діоксиду вуглецю досягає максимального значення, води - першого мінімуму за концентрації в межах 17,0 \%, інших поданих вище речовин - у межах 2,5 \%.

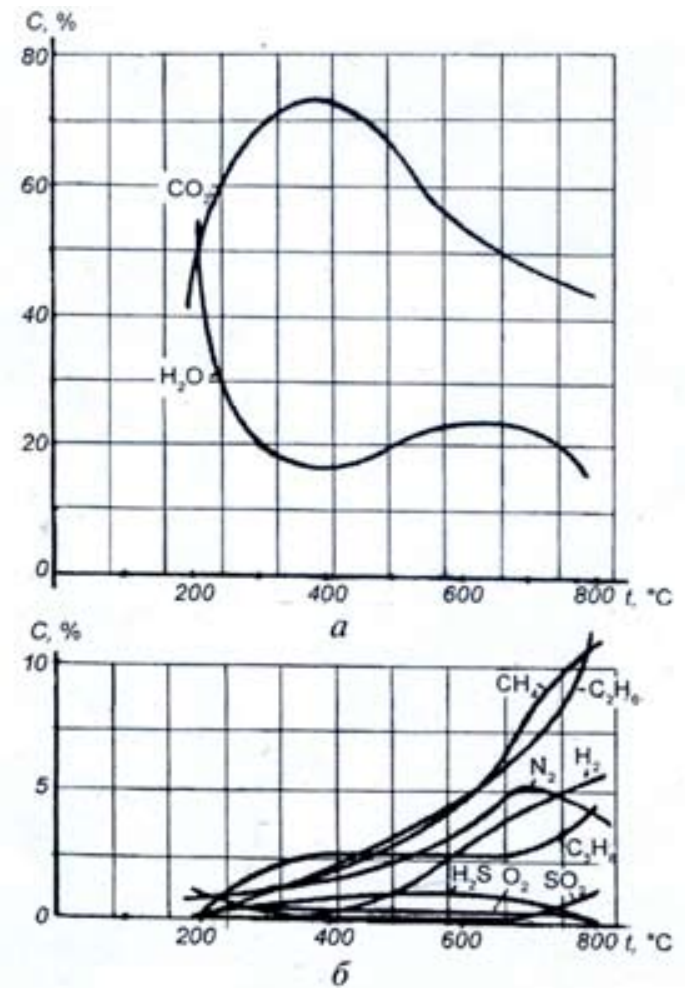

Температурна залежність концентрацій летких сполук із торфу 
Вугільні пласти Донбасу (марки ПС, П, НА), що утворилися за термодинамічних умов до температури $240{ }^{\circ} \mathrm{C}$, містять метан у концентраціях від 77 до $99 \%$. Якщо цей метан має органічну природу, то в цих пластах повинен бути діоксид вуглецю в концентрації 3000,0 \%. Ці леткі сполуки повинні бути законсервовані породами вугільного пласта з мінімумом дефектів, тобто фактично монокристалами, щоб сотні мільйонів років зберігати таку сполуку, як метан. Отримані експериментальні дані засвідчили, що наявний у вугільних пластах метан не утворився з органічних решток, тобто, має абіогенне походження (Сворень, Наумко, 2000; Сворень, 2008) і синтезувався за розробленим нами механізмом (Сворень, Наумко, 2006). Це стосується і «сланцевого» газу, погляди на генезу якого розвинені надалі (Naumko et al., 2017).

Отож, стисло викладені матеріали підтверджують вагомість підстав для виконання робіт такого плану з пошуку природних вуглеводнів, зокрема метану тощо. Енергетична скрута в державі вимагає нагально вжити заходів 3 викладеної проблеми і фінансового забезпечення робіт-розробок. Насамперед, це стосується фундаментальних наукових результатів та розроблених $\mathrm{i}$ апробованих технологій пошуків вуглеводнів, кольорових металів, діамантів тощо в надрах планети, які розроблені в Інституті геології і геохімії горючих копалин НАН України у м. Львові і перевірені практикою.

Щодо згадуваного підприємства, яке б використовувало фундаментальні наукові результати та нові технології пошуку й розробки родовищ з буріння свердловин українських учених, то у своїй діяльності воно могло б проводити роботи як на теренах України, так і за кордоном, у державах, з якими наша країна має угоди про науково-технічну співпрацю.

До чого призводить відсутність такого підприємства покажемо далі. Ще 2013 р. для пошуку й видобутку «сланцевого» газу Україна обрала британськонідерландську компанію «Shell», яка не володіє згаданими вище новітніми технологіями пошуків вуглеводнів і не застосовує їх, а результату досягає гідравлічним розривом пласта. Це викликало спротив населення Львівщини, Донеччини, Харківщини, на території яких заплановано ці роботи, зокрема, мітингувати проти видобутку «сланцевого» газу мешканці Донецька розпочали відразу після погодження Донецькою обласною радою в січні 2013 року проєкту угоди про розподіл вуглеводнів, які видобуватимуться в межах ділянки «Юзівська». Для дослідження іiї потенціалу на початковому етапі геологічного вивчення передбачалося буріння до 15 свердловин, а запланований видобуток мав досягнути 8-10 млрд м³/рік. Мітингувальники-мешканці регіонів незадоволені застосовуваними компанією «Shell» способами видобутку газу, які, за їхніми прогнозами, завдадуть непоправної шкоди природі, вони не хочуть дихати отруєним повітрям, споживати захімічені-забруднені води і вирощувати на забруднених чорноземах сільськогосподарську продукцію. Вони вимагали персональної відповідальності депутатів обласної ради за шкоду довкіллю, публічних громадських слухань і незалежної екологічної експертизи проєкту. Завдяки цим протестам, а також через ситуацію на Донбасі ці роботи вдалося призупинити. Станом на листопад 2014 р. компанія пробурила лише дві розвідувальні свердловини і не змогла провести повноцінної розвідки Юзівського родовища, розпочавши лише певні роботи в межах Харківської області, але продовжує роботу в регіоні. 
Щодо походження природного газу, то цій науковій проблемі автор віддав понад п'ятдесят років свого наукового життя і стверджує, що немає метану вугільного, і немає сланцевого газу-метану, є метан однієї генези $з$ дещо відмінним ізотопним складом Карбону, одначе синтезований за одним і тим самим механізмом у високотермобарних процесах (Сворень, Наумко, 2006; Наумко, 2006), який після міграції в земну кору нагромаджувався у вигляді покладів-родовищ, у порожнинах вугільних пластів, теригенних товщах, пісковиках тощо. Релікти ж глибинних відновних, практично істотно водневодневих безводних («сухих») флюїдів уперше встановлено у флюїдних включеннях у мінералах і закритих порах перспективних на «сланцевий» газ граптолітових аргілітів палеозою Волино-Поділля (Naumko et al., 2017). Зауважимо, що в земній корі біогенний метан утворювався й утворюється безперервно, однак у мінімальних концентраціях!

Щодо вугільного метану, то це питання обговорено в працях з термобарометрії та геохімії газів прожилково-вкрапленої мінералізації у відкладах нафтогазоносних областей і металогенічних провінцій: природа вугільного метану в контексті нового вирішення проблеми його синтезу-генези (Сворень, 2008; Наумко та ін., 2016), за даними яких встановлено невідому раніше властивість глибинного абіогенного метановмісного високотермобарного флюїду розкладати-перетворювати природні органічні рештки в пласти вугілля з одночасним їх метанонасиченням та його консервацією в земній корі (Сворень, 2018).

Тут важливо зауважити, що глибинний високотермобарний флюїд не завжди є вуглеводневмісним, може бути і діоксидвуглецевим тощо?! Якщо він $€$ іншим або його концентрація $є$ малою, то зрозуміло, скільки не розривай пласти, позитивного результату ніхто не отримає, кошти втратить і заподіє природі непоправної шкоди. 3 метою уникнення цього потрібно бурити параметричні свердловини і геохімічно добре вивчити отриманий керн відповідно до вимог вищезгаданих технологій пошуку вуглеводнів, після чого робити фахові висновки щодо продовження пошуків вуглеводнів чи припинення робіт.

Лише так ми отримаємо позитивний результат, заощадимо кошти і працю, збережемо лікувальні природні води в надрах України та інших країн.

I ще важливо: у вересні 2012 року в м. Бориславі було проведено Міжнародну наукову конференцію «Проблеми та перспективи нафтогазової промисловості України», у якій ми взяли участь i, зокрема, зазначили (Сворень, Наумко, 2012; Сворень, 2013), що нагальними завданнями залишаються визначення перспектив нафтогазоносності і джерел вуглеводнів та їхнього знаходження, виявлення негативного впливу на довкілля вуглеводнів, що неконтрольовано мігрують на денну поверхню з глибини. Мешканцям Борислава вуглеводневі сполуки, які заповнюють пивниці, криниці та насичують грунти, створюють багато клопотів...

На прикладі Бориславського вузла родовищ вуглеводнів, які постійно поповнюються-підживлюються самими надрами, що актуально і для всіх інших нафтогазоносних регіонів, показано необхідність застосування нових підходів для вирішення означених проблем.

Колектив нашого Інституту готовий взяти на себе основний тягар 3 вирішення цих проблем-завдань і скеровувати роботи з пошуків вуглеводнів на 
позитивний результат без нанесення шкоди довкіллю, виходячи 3 наявного наукового і практичного досвіду.

Так, дослідивши леткі сполуки з окремих флюїдних включень у мінералах, ми вперше у вакуумі встановили відсутність молекулярного водню, а також оксиду вуглецю в природних твердих тілах, і те, що леткі сполуки у вакуолях знаходяться у формі хімічних речовин, а в дислокаціях, субмікротріщинах і твердих розчинах - в атомарних формах, до прикладу, втілений водень.

При дослідженнях вмісту газово-рідких включень у мінералах різних родовищ і походження в ряді випадків фіксуються істотно газові вакуолі, приміром, чисто метанові чи переважно метанові включення в «мармароських діамантах». Водночас подібні - істотно газові діоксидвуглецеві включення встановлені і вивчені багатьма дослідниками в кальциті, кварці, бариті тощо, мінералах гідротермального утворення (походження).

На теренах Складчастих Карпат у низькотемпературних кварц-карбонатних жилах трапляються вуглеводневі сполуки у вигляді самостійних виділень, представлені чорною смолистою речовиною, яка утворила нальотинамазки на кальциті, що виповнює жили, та дисперсно розмазана в його тілі і законсервована включеннями в ньому.

3 допомогою мас-спектрометричного хімічного аналізу ми встановили, що істотно газові включення в «мармароському діаманті» із жил околиць с. Люта (Дуклянська зона, пізня крейда) містять, \% за об'ємом: $\mathrm{CH}_{4}-97,48$ i $\mathrm{N}_{2}-2,52$; аналогічні включення - с. Воловець відповідно: $\mathrm{CH}_{4}-97,66 \mathrm{i} \mathrm{N}_{2}-$ 2,34 . У «мармароському діаманті» з району с. Нижні Ворота (Кросненська зона, олігоцен) у включеннях типу $\mathrm{L}_{1}+\mathrm{L}_{2}+\mathrm{G}$ містяться, \% за об'ємом: $\mathrm{CH}_{4}-$ 62,$21 ; \mathrm{C}_{2} \mathrm{H}_{6}-6,71 ; \mathrm{C}_{3} \mathrm{H}_{8}-6,06 ; \mathrm{C}_{4} \mathrm{H}_{10}-3,97 ; \mathrm{C}_{5} \mathrm{H}_{12}-1,32 ; \mathrm{CO}_{2}-1,04 ; \mathrm{N}_{2}-5,37$; $\mathrm{H}_{2} \mathrm{O}-13,32$; а включення в «мармароському діаманті» (Нижні Ворота, Кросненська зона, G) містять лише метан (100 \%), істотно газові включення із жил с. Ставне, Дуклянська зона (пізня крейда), тип L $+\mathrm{G}$, у кальциті містять, об. \%: $\mathrm{CH}_{4}-88,16 ; \mathrm{C}_{2} \mathrm{H}_{6}-4,18 ; \mathrm{C}_{3} \mathrm{H}_{8}-2,89 ; \mathrm{CO}_{2}-1,04 ; \mathrm{N}_{2}-3,12 ; \mathrm{H}_{2}-0,61$.

Основним газовим компонентом включень у «мармароських діамантах» 3 різних місць Карпат $€$ метан, вміст якого найвищий. На вуглеводневий склад включень у них мало впливає вік порід із цими кварц-карбонатними жилами. Генетичний зв'язок кристаликів «мармароських діамантів» із тектонічними розломами-розривами як доказ синтезу мінералу під час міграції вуглеводневмісних і мінерало-породоутворювальних флюїдів та зміни полікомпонентного флюїду в часі, особливо інтенсивно в момент збагачення водою, - важливий пошуковий критерій природного газу, нафти та інших вуглеводнів у земних надрах.

Отож, з'ясовано, що в час втілення в земну кору глибинного високотемпературного флюїду паралельно проходить розпад контактних з ним карбонатів на окремі складові $\left(\mathrm{CaO}\right.$ і $\left.\mathrm{CO}_{2}\right)$ за температури вище $675{ }^{\circ} \mathrm{C}$, які разом з $\mathrm{H}_{2} \mathrm{O}$ за температури нижче $580^{\circ} \mathrm{C}$ утворюють «вапняне молоко» і в суміші 3 домішковими вуглеводнями разом переносяться на значні відстані. $\mathrm{CO}_{2}, \mathrm{CH}_{4}$ та інші $\mathrm{C}_{n} \mathrm{H}_{m}$, пара $\mathrm{H}_{2} \mathrm{O}$ з низькими коефіцієнтами внутрішнього тертя і температурою від $580{ }^{\circ} \mathrm{C}$ і нижче дозволяють флюїдові мігрувати на значні відстані й герметично замінералізовувати найрізноманітніші порожнини та за геометрією й розмірами макро- і мікротріщини. 
Ще стисло про калорійність природного газу-метану, яку вже обговорено (Сворень, 2019). Термін «природний газ» свідчить, що ця корисна копалина утворилася-синтезувалася в надрах Землі за складних фізико-хімічних процесів, відтворених численними теоретичними та експериментальними дослідженнями, зокрема і нашими (Сворень, 1992; Сворень, Наумко, 2006 та ін.). Фактично природний газ $є$ сумішшю вуглеводневих газів у різних концентраціях, \%: метану $-90-97$; етану $-1,50-9$; пропану $-0,50-4,0$; ізобутану 0,06 ; н-бутану $-0,05$; пентанів - 0,025; гексанів та вищих $-0,003$; азоту 0,85 ; діоксиду вуглецю - 0,06; інших відомих газів у малих концентраціях і води, яка в земній корі в значних об'ємах контактує із вказаними газами, які одночасно взаємодіють 3 цією водою і розчиняються в ній унаслідок їхньої специфічної електронної будови та наявного великого тиску.

Природний газ у сховища надходить з різних родовищ традиційного типу.

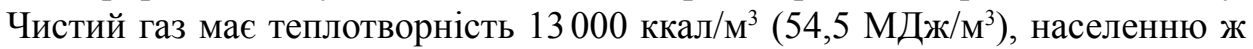
його постачають - у межах 7600 ккал/ $\mathrm{M}^{3}$, а насправді вона $\epsilon$ ще меншою.

Практично до вищевказаної суміші можуть ще додавати нафтовий (супутній) газ, газ (метан) вугільних родовищ та газ сланцевих товщ, газ колекторів щільних порід, газ центральнобасейнового типу (далі - природний газ) суміш вуглеводнів та невуглеводневих компонентів 3 парою води, що перебувають у газоподібному стані за стандартних умов $\left(p=1,0\right.$ бар i $\left.t=+20^{\circ} \mathrm{C}\right)$ і $€$ товарною продукцією. До відома: 1,0 бар = 0,1 МПа.

Ці вуглеводневі гази мають унікальну властивість взаємодіяти з водою та в конкретних термодинамічних умовах синтезувати газогідрати у формах знаходження (M- $\left.n \mathrm{H}_{2} \mathrm{O}\right): \mathrm{CH}_{4} \cdot 6 \mathrm{H}_{2} \mathrm{O}$ - гідрат метану; $\mathrm{C}_{2} \mathrm{H}_{6} \cdot 6 \mathrm{H}_{2} \mathrm{O}-$ гідрат етану; $\mathrm{C}_{3} \mathrm{H}_{8} \cdot 6 \mathrm{H}_{2} \mathrm{O}$ - гідрат пентану; $\mathrm{C}_{4} \mathrm{H}_{10} \cdot 6 \mathrm{H}_{2} \mathrm{O}$ - гідрат бутану; зокрема, за температури $0{ }^{\circ} \mathrm{C}$ : гідрат метану синтезується за тиску 3,0 МПа, гідрат етану $0,5 \mathrm{MПа,} \mathrm{гідрат} \mathrm{пропану}-0,15$ МПа тощо. Для зберігання гідрату метану за кімнатної температури $\left(\sim 25^{\circ} \mathrm{C}\right)$ потрібний тиск у межах 40,0 МПа.

Теплотворна здатність природного газу залежить від його складу та наявних домішок у суміші з парою води. Відповідно ця суміш різних газів 3 водою постачається споживачам з різко пониженою калорійністю від 13000 до 7600 ккал/куб. м і менше, які при згоранні і дають понад удвічі меншу кількість тепла. На якість природного газу, який нам постачають, і на домішки в ньому впливає те, що зміною тиску та температури природних газів у сховищах, газгольдерах, різних установках з гідратами вуглеводневих газів можна від них відривати воду в потрібній концентрації, що вже буде збільшеною домішкою в трубах, якими транспортують газ до наших осель. Тобто, основною домішкою, яка різко погіршує теплотворність природного газу, $\epsilon$ пара води, яка утворюється в трубопроводах у процесах розпаду газогідратів, найбільш інтенсивно - 3 гідрату пентану.

У підсумку теоретичними та експериментальними дослідженнями стверджено, що природний метан у надрах Землі синтезувався за одним і тим самим механізмом в абіогенних високотермобарних глибинних процесах, лише 3 дещо відмінним ізотопним складом Карбону, та після міграції в земну кору нагромаджувався у вигляді покладів-родовищ нафти і газу, газовуглепородних масивів, «сланцевих» теригенних товщ тощо. Виходячи 3 цих передумов, пошуки родовищ-покладів вуглеводнів необхідно проводити 
відповідно до розроблених «нової технології визначення перспективи нафтогазоносності локальної площі», «фізико-хімічної моделі синтезу вуглеводнів і способу геохімічного пошуку їхніх покладів», «нової теорії синтезу і генезису вуглеводнів у літосфері Землі: абіогенно-біогенний дуалізм», тобто основу вирішення завдання оптимізації геолого-пошукових робіт мають складати новації фундаментальної геологічної науки, а не технічні проблеми, зокрема гідравлічний розрив пласта.

Давиденко, М. М., Сворень, Й. М. (1994). Спосіб локального прогнозування збагачених ділянок золоторудних полів. Промислова власність. Офіційний бюлетень, 3.

Наумко, І. М. (2006). Флюїдний режим мінералогенезу породно-рудних комплексів України (за включеннями у мінералах типових парагенезисів). (Автореф. дис. д-ра геол. наук). Інститут геології і геохімії горючих копалин НАН України, Львів.

Наумко, I. М., Павлюк, М. І., Сворень, Й. М., Зубик, М. І. (2016). Гази вугільних родовищ: нове вирішення проблеми синтезу-генезису метану. Доповіді НАН Укра$\ddot{і н и, ~ 3, ~ 61-68 . ~}$

Наумко, И. М., Сворень, И. М. (2003). О важности глубинного высокотемпературного флюида в создании условий для формирования месторождений природных углеводородов в земной коре. В Новые идеи в науках о Земле: Материалы VI Международной конференции (Москва, 8-12 апреля 2003 г.) (Т. 1, с. 249). Москва.

Наумко, І., Сворень, Й. (2014). Нові технології пошуків корисних копалин, основані на дослідженнях флюїдних включень у мінералах. В Актуальные проблемы поисковой и экологической геохимии: Сборник тезисов Международной научной конференции (Киев, 1-2 июля 2014 г.) (с. 23-25). Киев: Інтерсервіс.

Сворень, И. М. (1984). Примеси газов в кристаллах минералов и других твердых телах, их способы извлечения, состав, форма нахождения и влияние на свойства веществ. (Автореф. дис. канд. техн. наук). Институт геологии и геохимии горючих ископаемых АН УССР, Львов.

Сворень, Й. М. (1992). Питання теорії генезису природних вуглеводнів та шляхи пошуку їх покладів. В Тектогенез і нафтогазоносність надр України: тези доповідей наукової наради (20-22 жовтня 1992 р.) (с. 143-145). Львів.

Сворень, Й. М. (2008). Термобарометрія і геохімія газів прожилково-вкрапленої мінералізації у відкладах нафтогазоносних областей і металогенічних провінцій: природа вугільного метану. Уголь Украины, 8 (620), 42-46.

Сворень, Й. (2013). Термобарометрія та геохімія газів прожилково-вкрапленої мінералізації у відкладах нафтогазоносних областей і металогенічних провінцій: дефекти в мінералах - джерело інформації про процеси мінералоутворення. Мінералогічний збірник, 63 (2), 91-97.

Сворень, Й. (2018). Властивість глибинного абіогенного метановмісного високотермобарного флюїду утворювати вугілля. Геологія і геохімія горючих копалин, 3-4 (176-177), 105-109.

Сворень, Й. (2019). Про новий підхід до визначення теплотворності природного газу, який постачають споживачам, та його кубометробарометрію. Геологія і геохімія горючих копалин, 2 (179), 84-89.

Сворень, Й. М., Давиденко, М. М. (1994). Спосіб визначення перспективи нафтогазоносності локальної площі. Промислова власність. Офіційний бюлетень, 4.

Сворень, Й. М., Давиденко, М. М. (1995). Термобарометрія і геохімія газів прожилково-вкрапленої мінералізації у відкладах нафтогазоносних областей і металогенічних провінцій. Доповіді НАН Украӥни, 9, 72-73. 
Сворень, Й. М., Давиденко, М. М., Гаєвський, В. Г., Крупський, Ю. З., Пелипчак, Б. П. (1994). Перспективи термобарометрії і геохімії газів прожилково-вкрапленої мінералізації у відкладах нафтогазоносних областей і металогенічних провінцій (новий науковий напрямок в геології). Геологія і геохімія горючих копалин, 3-4 (88-89), 54-63.

Сворень, Й. М., Наумко, І. М. (2000). Нова технологія визначення генезису вуглеводневих газів. В Нафта і газ Украӥни (Т. 1, с. 118). Івано-Франківськ: УНГА.

Сворень, И. М., Наумко, И. М. (2003). Роль адиабатических явлений в процессах накопления-концентрации и превращения углеводородсодержащих веществ в литосфере Земли. В Новые идеи в науках о Земле: Материалы VI Международной конференции (Москва, 8-12 апреля 2003 г.) (Т. 1, с. 257). Москва.

Сворень, Й. М., Наумко, І. М. (2006). Нова теорія синтезу і генезису природних вуглеводнів: абіогенно-біогенний дуалізм. Доповіді НАН Украӥни, 2, 111-116.

Сворень, Й., Наумко, І. (2012). Бориславське вуглеводневе родовище: проблеми для роздумів. В Стан, проблеми та перспективи нафтогазової промисловості Украйни: Збірник тез доповідей Міжнародної науково-практичної конферениії (Львів, 7-9 вересня 2012 р.) (с. 16). Львів: Видавництво Львівської політехніки.

Сворень, Й. М., Наумко, І. М., Давиденко, М. М. (1998). Нова технологія визначення перспективи нафтогазоносності локальної площі. В Нафта-Газ Украӥни - 1998: Матеріали V Міжнародної конферениії (Полтава, 15-17 вересня 1998 р.) (Т. 1, c. 111-112). Полтава: УНГА.

Naumko, I. M., Kurovets', I. M., Zubyk, M. I., Batsevych, N. V., Sakhno, B. E., \& Chepusenko, P. S. (2017). Hydrocarbon compounds and plausible mechanism of gas generation in "shale" gas prospective Silurian deposits of Lviv Paleozoic depression. Geodynamics, 1 (22), 26-41.

Svoren', J. M., Naumko, I. M., Kovalyshyn, Z. I., Bratus', M. D., \& Davydenko, M. M. (1999). New technology of local forecast of enriched areas of gold ore fields. B Hayкові основи прогнозування, пошуків та оиінки родовищ золота: Матеріали Міжнародної наукової конференції (Львів, 27-30 вересня 1999 р.) (с. 121-125). Львів: Видавничий центр ЛДУ ім. І. Франка.

Стаття надійшла: 25.10.2019

\section{Yosyp SVOREN}

\section{BOWELS OF THE EARTH - NATURAL PHYSICAL-CHEMICAL REACTOR: IS THE SEARCH FOR NATURAL METHANE A FUNDAMENTAL SCIENCE OR A TECHNICAL PROBLEM?}

It is shown that the hypothesis of organic origin of hydrocarbons doesn't respond to the presence of a dominant concentration of methane in sediments, deposits, "shale' series and so on, hence prospecting and exploration for hydrocarbon deposits in them are conducted in most cases intuitively, but not on the fundamental scientific basis.

Experimental studies based on the heating of slightly modified organic matter (peat) show that up to $200{ }^{\circ} \mathrm{C}$ in the process of its decomposition the following gases were delivered (vol. \%): $\mathrm{CO}_{2}=49.5 ; \mathrm{H}_{2} \mathrm{O}=49.3 ; \mathrm{CH}_{4}, \mathrm{C}_{2} \mathrm{H}_{6}, \mathrm{C}_{3} \mathrm{H}_{8}, \mathrm{~N}_{2}, \mathrm{H}_{2}, \mathrm{SO}_{2}, \mathrm{H}_{2} \mathrm{~S}$ within $1.2 \%$ in total.

It is confirmed that there is no coal methane, there is no shale gas-methane, but there is methane of one genesis with slightly different isotope composition of carbon, 
but synthesized according to the same mechanism in the high-thermobaric processes that after migration into the earth's crust accumulated in the form of deposits in cavities of coal seams, terrigenous units, sandstones and so on.

Prospecting for pool-deposits of hydrocarbons should be carried out in conformity with developed "new technology of determination of prospects for oil and gas presence in the local area", "physical-chemical model of synthesis of hydrocarbons and the way of geochemical searching for their occurrences", "new theory of hydrocarbon synthesis and genesis in the earth's lithosphere: abiogenic-biogenic dualism".

Keywords: fluid inclusions, minerals, methane, origin of hydrocarbons, exploration, pool-deposits, new technologies. 